\title{
DVLA regulations concerning driving and psychiatric disorders
}

\section{Knowledge and attitudes of psychiatrists}

\author{
Paul Thompson and Deborah Nelson
}

Drtving during and afier a poychiatile lliness is an important area cbout which relatively ittile has been wittien. This paper reports on a questionnaire study olmod af seeking poychlatists' knowledos and viows on this lesue. Of 187 questionnolres distributed 101 were retumed, and replies incicated that poychiatilits are generally unaware of regulations currently in force. suggeetions on how to improve matters are made.

Despite a recent fall in the annual number of fatalities on British roads, driving accidents remain a leading cause of morbidity and mortality. It has been estimated that a quarter of all road accidents involve drivers whose skills are impaired by either alcohol, lllness, emotional turmoll or drugs (Cremona, 1986). The link between alcohol and road traffic accidents is well documented but driving and fitness to drtve during and after a psychiatric illness is a more difficult area. Not only can certain psychiatric conditions make driving hazardous, but sideeffects of psychotropic drug medication can impair psychomotor performance.

Apart from a few exceptions, relattvely little work has studied driving ability in psychiatric illness (Metzner et al, 1993). One notable exception has been the driving habits of patients with dementia. Many patients continue to drive after the diagnosis has been made and as one might expect driving skills deteriorate as the illness progresses, with greater likelihood of accidents (O'Neill, 1993).

British law is clear in making it the responsibility of the licence holder (or applicant) to notify the Drtver and Vehicle Licensing Agency (DVLA) if they develop a medical condition affecting fitness to drive. Good medical practice requires doctors to inform patients if they fall into this category. To satisfy this requirement doctors should have a sufficiently detailed knowledge of current guidelines so as to advise patients both for their own safety and that of the general public.

\section{The study}

A questionnaire was sent to all general adult psychiatrists working in Lothian. Dundee and Fife. Questions included those relating to DVLA regulations regarding fitness to drive for Group 1 licences (motorcycles and cars) when suffering from neuroses, psychoses, dementia and substance abuse. Questions also enquired about knowledge relating to whose responsibility fitness to drive was and whether current regulations were felt to be too strict or too lax. The study was primarily interested in assessing when there was a change in the ability to drive and for this reason questions relating to learning disability and personality disorders were excluded. Anonimity of the respondents was assured.

\section{Findings}

In total, 101 questionnaires were returned and this represented response rates of $44 \%$ (52 from 119) for Lothian, 77\% (33 from 43) for Dundee and $64 \%$ (16 from 25) for Fife. Table 1 summarises the current DVLA regulations for various conditions and the accuracy of psychiatrists' knowledge. As a group, senior reglstrars were most knowledgeable about the regulations. For example, $65 \%$ of senior registrars were aware of the regulation concerning psychosis, whereas consultants and registrars were correct in $16 \%$ and $11 \%$ of cases respectively. The majority of psychiatrists (56\%) knew it was the responsibility of the patient to inform the DVLA if they were unfit to drive, although $19 \%$ of respondents thought it should be the responsibility of the general practitioner. The advice given by psychiatrists to patients concerning DVLA regulations and effects of medication on driving ability is shown in Table 2. Regarding how psychiatrists viewed current regulations, $11 \%$ saw them as too strict, 37\% thought they were too lax, while 39\% 
ORIGINAL PAPERS

Table 1. DVLA regulations conceming fithess to ditive and psychlatilc illness: knowledge of psychlatists

\begin{tabular}{|c|c|c|c|c|}
\hline \multirow[b]{2}{*}{ Area } & \multirow[b]{2}{*}{ Roculation } & \multicolumn{3}{|c|}{ Peychichtids' reeponse (7) } \\
\hline & & Correct & Incomect & $\begin{array}{l}\text { Do not } \\
\text { know }\end{array}$ \\
\hline Neurosis & $\begin{array}{l}\text { Dituing need not cease ofter } \\
\text { neurotic lliness }\end{array}$ & 88 & 8 & 4 \\
\hline Psychosis & $\begin{array}{l}\text { 6-12 months off the road after } \\
\text { psychosts requiring hospltal } \\
\text { admission }\end{array}$ & 28 & 67 & 5 \\
\hline Early dementia & $\begin{array}{l}\text { Dituing permilted if no significant } \\
\text { dlsorlentation and insight and } \\
\text { judgement retained }\end{array}$ & 64 & 26 & 10 \\
\hline Late dementia & Licence refused/revoked & 94 & 4 & 2 \\
\hline $\begin{array}{l}\text { Alcohol dependence } \\
\text { syndrome }\end{array}$ & $\begin{array}{l}\text { Lcence removed/revoked for at } \\
\text { least } 1 \text { year }\end{array}$ & 36 & 56 & 8 \\
\hline $\begin{array}{l}\text { Selzure associated with } \\
\text { alcohol withdrowal }\end{array}$ & $\begin{array}{l}\text { Perlod of } 1 \text { year off the road } \\
\text { ( } 2 \text { years if more than one } \\
\text { selzure) }\end{array}$ & 60 & 31 & 9 \\
\hline $\begin{array}{l}\text { Cannabls addiction/use/ } \\
\text { dependency } \\
\text { Amphetamine/cocaine/ }\end{array}$ & 6 months off diving & 14 & 81 & 5 \\
\hline dependency & 12 months off dituing & 19 & 75 & 6 \\
\hline
\end{tabular}

thought they were about right. The remaining $13 \%$ could not decide.

\section{Comment}

Although the overall response rate to the questionnaire was encouraging (54\%), a significant proportion of psychiatrists failed to reply. Lack of knowledge of DVLA regulations could have contributed to this. Our aim was to assess working knowledge of the regulations so a questionnaire of this nature is flawed as theoretically, replies could be looked up prior to filling it in. Even so, the study has revealed considerable gaps in knowledge of current regulations. Respondants were especially unaware of regulations concerning psychosis, with only $28 \%$ knowing a patient had to have 6-12 months off the road after an episode of psychosis of whatever type which required hospital admission. In addition, many will be surprised at the requirement to refrain from driving for six months after cannabis misuse and 12 months after amphetamine, opiate or cocaine abuse or dependency.

The relattvely high percentage of doctors (approximately 75\%) who do not regularly discuss DVLA regulations with appropriate patients is worthy of comment. In most cases the responsibility rests with the patient but there could be legal implications if a patient was not warned of the risks of driving when psychiatrically unwell, and this was used as a defence in court. Indeed the literature quotes a case in the USA of a psychiatrist being sued for malpractice on these grounds (Hollister, 1992). A position statement by the American Psychiatric Association has recently attempted to clarify the role of psychiatrists in assessing driving ability (Reifler et al, 1995). Essentially this highlights their

Table 2. Advice given by psychiatrists to patients concerning psychiatric lliness and driving

\begin{tabular}{|c|c|c|c|c|c|}
\hline \multirow[b]{2}{*}{ Qucetion } & \multicolumn{5}{|c|}{ Pyychlotitits' respones (\%) } \\
\hline & Anways & Uauctly & Rerrely & Nover & Do not know \\
\hline $\begin{array}{l}\text { In appropriate cases do you inform } \\
\text { patlents about DVLA regulations if } \\
\text { they dilve? }\end{array}$ & 3 & 20 & 59 & 15 & 3 \\
\hline $\begin{array}{l}\text { Do you discuss effects of psychotroplc } \\
\text { medication on diving abillty in } \\
\text { relevant potilents? }\end{array}$ & 19 & 57 & 21 & 3 & 0 \\
\hline
\end{tabular}


educational role rather than making routine assessments and/or reporting concerns to regulatory departments. It recognises that a process which allows, but does not require, concerns to be volced in the face of clear evidence of impaired driving is desirable to society.

It is difficult to interpret psychiatrists' views on whether regulations are deemed too lax or strict in view of the gaps in knowledge. It is of interest that as a group senior registrars tended to know the regulations better than most grades, and there was a slight tendency for them to regard the regulations as too strict. Although the study did not enquire about which particular regulations were deemed too strict, there could be a wide variation in risk posed by patients within each diagnostic grouping. For example, in the case of psychosis, risk could rest on the degree of insight and therefore on compliance with medication as well as the nature of the psychopathology. Risk to other drtvers could be considerable if symptoms when unwell included persecutory delusions concerning other road users.

The issue of drtving soon after a psychiatric illness is one which has possibly been neglected by doctors in the past. Trainees in particular indicated that they would welcome more information concerning this issue. Many seemed to be unaware of the publication entitled At a Glance Guide to the Current Medical Standards of Futness to Drive which is issued by the Medical Advisory Branch of the DVLA (1993). Ensuring new trainees recetved a copy of this on commencing work would seem appropriate. Discussion of difficult cases with senior colleagues may be necessary as informing patients of current regulations may put strain on the doctor-patient relationship and may even result in a patient withdrawing from treatment if not handled carefully.

\section{References}

CREMONA, A. (1986) Mad drtvers: peychiatric illness and drtving performance. Brttish Journal of Hospttal Medictne, 86, 193-195.

HOUSTER, L. E. (1992) Automoblle ditving by poychtatric patients. American Journal of Psychiatry, 149, 274.

MEDICAL ADVISORY BRANCH OF THE DVLA (1993) At a Glance Guide to the Current Medical Standards of Funess to Drtue. Swansea: DVLA.

Metzaner, J. L., Dentino, A. N., Godard, S. L., et al (1993) Impairment in drtving and poychlatric illness. Joumal of Newropsychiatry, 8, 211-220.

O'NEnL. D. (1993) Drtving and dementla. Alzhetmer's Review. 3.

REITLER, B. V. (1995) Posttion statement on the role of poychiatrists in assessing drtving ability. American Journal of Psychtatry. 182, 819.

-Paul Thompson, Clinical Lecturer, Department of Psychiatry, Ninewells Hospttal and Medical School, Dundee DD1 9SY; and Deborah Nelson, Registrar in Psychiatry, Stratheden Hospital, Cupar, Fyfe PY15 5RR

*Correspondence 